\title{
KESANTUNAN TINDAKTUTUR DIREKTIF DALAM NOVEL TERJEMAHAN HARRY POTTER TAHUN 1 DAN 2 KARYA $J$. K. ROWLING SERTA RELEVANSINYA SEBAGAI BAHAN AJAR DI SMP
}

\author{
Agus Sriyatmoko, Purwadi, Raheni Suhita \\ Universitas Sebelas Maret \\ Surel: agus.sriyatmoko354@gmail.com
}

\begin{abstract}
Abstrak: Tujuan penelitian ini adalah mendeskripsikan (1) bentuk tindak tutur direktif dalam novel Harry Potter tahun 1 dan 2 karya J.K Rowling, (2) bentuk kesantunan berbahasa, (3) relevansi novel Harry Potter tahun 1 dan 2 dalam pembelajaran Bahasa Indonesia pada siswa di SMP. Teknik pengumpulan data yang digunakan dalam penelitian ini adalah purposive sampling dan analisis data menggunakan model analisis interaktif.Hasil penelitian ini menunjukkan bahwa bentuk tindak tutur direktif dan pematuhan prinsip kesantunan yang terdapat dalam novel Harry Potter tahun 1 dan 2 karya J.K Rowling adalah sebagai berikut: (1) tindak tutur; permintaan, pertanyaan, memerintah, larangan, pemberian izin, dan bentuk tuturan direktif menasihati yang berjumlah 419 data;(2) pematuhan prinsip kesantunan guru dan siswa selama proses pembelajaran berlangsung ditemukan sebanyak 118 data;(3) novel Harry Potter tahun 1 dan 2 karya J. K. Rowling ada keterkaitandengan pembelajaran sastra di Sekolah Menengah Pertama (SMP).
\end{abstract}

Kata kunci: tindak tutur, kesantunan berbahasa, pembelajaran.

\section{DIRECTIVES SPEECH ACT IN $1^{\text {st }}$ AND $2^{\text {nd }}$ YEAR OF HARRY POTTER TRANSLATION NOVELS BY J. K. ROWLING AND ITS RELEVANCE AS LEARNING MATERIALS IN JUNIOR HIGH SCHOOL}

\begin{abstract}
The purpose of this study is to describe (1) the form of directive speech acts in JK Rowling's Harry Potter novels year 1 and 2, (2) the form of language politeness, (3) the relevance of the Harry Potter novelsyear 1 and 2 in Indonesian language learning to students in middle school. The data collection technique used in this study was purposive sampling and data analysis used an interactive analysis model. The results of this study indicate that the form of directive speech acts and compliance with the principles of politeness contained in the Harry Potter novels year 1 and 2 by J. Rowling are as follows: (1) speech acts; requests, questions, rules, prohibitions, granting permits, and directive forms of counseling which numbered 419 data; (2) compliance with the principles of teacher and student politeness during the learning process is found as many as 118 data; (3) Harry Potter novels year 1 and 2 by J. K. Rowling are related to literary learning in junior high schools.
\end{abstract}

Keywords: pragmatics, speech acts, language politeness, learning.

\section{PENDAHULUAN}

Bahasa adalah alat yang paling utama untuk berkomunikasi dan berinteraksi antarmanusia untuk berbagai tujuan. Bahasa dapat digunakan untuk menyampaikan ide, gagasan, keinginan, perasaan, informasi, atau pesan kepada orang lain. Aktivitas berbahasa merupakan kegiatan yang menggunakan bahasa sebagai medianya, dengan tujuan untuk menyampaikan suatu maksud kepada orang lain. Tanpa adanya bahasa, manusia tidak dapat menyampaikan gagasannya, tidak dapat menolak atau menerima apa yang diinginkan atau tidak 
diinginkannya, dan tanpa bahasa manusia tidak dapat bersosialisasi dengan masyarakat.

Sebuah tuturan yang diujarkan oleh penutur dapat menimbulkan suatu efek terhadap mitra tutur, yaitu dengan adanya tindak verbal sebagai akibat dari adanya tuturan yang diujarkan. Tuturan bukan merupakan ujaran yang begitu saja keluar secara sia-sia, melainkan ujaran-ujaran tersebut mengandung maksud tertentu yang sepenuhnya terlihat secara eksplisit dan juga implisit atau disebut dengan implikatur, seperti dinyatakan oleh Searle (dalam F.X. Nadar, 2009:12) yang mengembangkan hipotesis mengenai tindak tutur bahwa "Pada hakikatnya semua tuturan mengandung arti tindakan, dan bukan hanya tuturan yang mempunyai kata kerja performatif".

Menurut Searle (dalam Rohmadi, 2004) tindak tutur direktif adalah tindak tutur yang dilakukan oleh penuturnya dengan maksud agar lawan tuturnya melakukan tindakan yang disebutkan dalam ujaran itu, misalnya menyuruh, memohon, menuntut, menyarankan, dan menantang dan tindak tutur ekspresif, yaitu tindak tutur yang dilakukan dengan maksud agar ujaranya diartikan sebagai evaluasi tentang hal yang disebutkan dalam ujaran itu, misalnya memuji, mengucapkan terima kasih, mengritik dan mengeluh. Di samping itu, ada faktor lain yang berpengaruh terhadap tindak tutur, antar lain faktor lingkungan siswa yang kurang santun dalam berkomunikasi. Baik faktor lingkungan bermain maupun lingkungan keluarga.

Sehubungan dengan penelitian yang relevan, penulis merujuk pada penelitian yang dilakukan oleh Rossida Ayu Wardhani D. R. pada tahun 2014 yang berjudul Tindak Tutur Direktif dan Strategi Kesantunan Berbahasa DAI pada Wacana Dakwah Dialogis Acara "Kata Ustad Solmed". "Serapan Hati", dan "Cahaya Hati" Di
Televisi (Suatu Pendekata Pragmatik). Penulis merujuk pada penelitian yang dilakukan oleh Rossida Ayu, sebab di dalam penelitian juga sama-sama mengkaji tentang tindak tutur direktif dan mengkaji tentang kesantunan berbahasa.Kemudian penulis mengkolaborasikannya dalam pembelajaran yang ada pada siswa tingkat SMP kelas VIII.

Berdasarkan latar belakang tersebut, dipandang perlu untuk mengadakan penelitian pada novel Harry Potter tahun 1 dan 2 karaya J.K Rowling dalam kajian pragmatik dan relevansi novel tersebut dalam pembelajaran di SMP, dengan judul "Kesantunan Tindak TuturDirektifdalam Novel Terjemahan Harry Potter Tahun 1 dan 2 Karya J. K. Rowling sertaRelevansinya sebagai Bahan Ajar diSMP”.

Penelitian ini bertujuan untuk mendeskripsikan dan menjelaskan mengenai (1) bentuk tindak tutur direktif dalam novel Harry Potter tahun 1 dan 2 karya J.K Rowling, (2) bentuk kesantunan berbahasa, (3) relevansi novel Harry Potter tahun 1 dan 2 dalam pembelajaran Bahasa Indonesia pada siswa di SMP.

Beberapa hasil penelitian yang relevan digunakan peulis sebagai acuan agar dapat mempunyai kebaharuan khususnya penelitian bahasa di bidang pragmatik.Penelitian yang dilakukan oleh sobhani dan Saghebi memiliki persamaan dan perbedaan dengan penelitian ini. Persamaannya yaitu kedua penelitian ini membahas tentang pelanggaran prinsip kerja sama sehingga menimbulkan implikatur percakapan. Namun, Sobhani dan Saghebi (2014) hanya meneliti prinsip kerja sama saja tidak meneliti prinsip kesantunan yang juga termasuk ke dalam prinsip percakapan. Perbedaan penelitian ini dengan Sobhani dan saghebi adalah penelitian ini memfokuskan pada kedua prinsip percakapan, yaitu prinsip kerja sama dan prinsip kesantunan. Perbedaan fokus penelitian tersebut juga menjadi pembeda antara penelitian ini 
dengan penelitian sebelumnya terletak pada objek penelitian di mana penelitian Sobhani dan Saghebi dalam bidang psikologi yang melibatkan psikiater (terapis) dan pasien, sedangkan penelitian ini dalam bidang pendidikan yang melibatkan guru dan siswa.

Sehubungan dengan penelitian yang relevan selannjutnya, penulis merujuk pada penelitian yang dilakukan oleh Rossida Ayu

Wardani D. R. pada tahun 2014 yang berjudul Tindak Tutur Direktif dan Strategi

Kesantunan Berbahasa DAI pada Wacana Dakwah Dialogis Acara "Kata Ustad Solmed". "Serapan Hati", dan "Cahaya Hati"

Di Televisi (Suatu Pendekata Pragmatik). Penulis merujuk pada penelitian yang dilakukan oleh Rossida Ayu, sebab di dalam penelitian juga sama-sama mengkaji tentang

tindak tutur direktif dan mengkaji tentang

kesantunan berbahasa.Kemudianpenulis mengkolaborasikannya dalam pembelajaran yang ada pada siswa tingkat SMP kelas VIII.

Istilah pragmatik pertama kali

dimunculkan oleh Charles Morris yang membedakan tiga konsep dasar dalam semiotik (Rohmadi, 2004). Ketiga konsep dasar tersebut meliputi : (a) sintaksis, yaitu telaah mengenai hubungan formal antara tanda dengan makna secara structural; (b) semantik, yaitu telaah mengenai hubungan tanda dengan objek yang mewadai tanda tersebut, dan (c) pragmatik, yaitu telaah mengenai tanda dengan penafsir.

Konteks sangat penting dalam kajian pragmatik. Konteks ini didefinisikan oleh Leech (dalam F.X. Nadar, 2009:6) sebagai "background knowledge assumed to be shared by $s$ and which contributes to $h$ "s interpretation of what $s$ means by a given utterance". Latar belakang pemahaman yang dimiliki oleh penutur maupun lawan tutur sehingga lawan tutur dapat membuat interpretasi mengenai apa yang dimaksud oleh penutur pada waktu membuat tuturan tertentu" (s berarti speaker "penutur"; $h$ berarti hearer "lawan tutur"). Dengan demikian, konteks adalah hal-hal yang bergayut dengan lingkungan fisik dan sosial sebuah tuturan ataupun latar belakang pengetahuan yang sama-sama dimiliki oleh penutur dan mitra tutur dan yang membantu mitra tutur menafsirkan makna tuturan.

Penelitian ini yang relevan dengan pembelajaran di SMP sesuai dengan KD 13.2 yaitu memahami unsur intrinsik novel remaja (asli atau terjemahan) yang dibacakan siswa. Sebagai bahan ajar yang merujuk dari KD tersebut, penelitian ini telah melalui proses review informan yang dilakukan terhadap guru dan siswa. Bahan ajar adalah seperangkat sarana atau alat pembelajaran yang berisikan materi pembelajaran, metode, batasan-batasan, dan cara mengevaluasi yang didesain secara sistematik dan menarik dalam rangka mencapai tujuan yang diharapkan, yaitu mencapai kompetensi atau subkompetensi dengan segala kompleksitasnya, hal tersebut diungkapkan oleh Widodo \& Jasmadi (dalam Lestari, 2013:1). SedangkanTasri berpendapat bahwa bahan ajar adalah segala bentuk konten baik teks, audio, foto, video, animasi, dan lainlain yang dapat digunakan untuk belajar.Kedua pendapat tersebut dapat ditarik kesimpulan bahwa bahan ajar adalah segala bentuk baik berbentuk cetak maupun noncetak yang diguankan guru dalam proses belajar guna mencapai tujuan pembelajaran.

Dalam suatu percakapan apalagi dalam suatu pembelajaran, penutur dapat menyampaikan gagasannya seandainya lawan tuturnya bekerja sama. Kesalahpahaman terkadang terjadi, tetapi kebanyakan penutur dan lawan tutur dapat saling memahami maksud tuturan yang mereka buat. Hal ini sejalan dengan Li (2015) dalam penelitiannya yang berjudul The Application of Cooperative Principle in Oral English Learning menyimpulkan bahwa prinsip kerja sama memberikan konstribusi yang sangat besar untuk pembelajaran bahasa Inggris di China, 
terutama dalam studi bahasa Inggris lisan sebab pengembangan ekonomi dan budaya, komunikasi internasional bergantung lebih pada bahasa Inggris. Begitu belajar bahasa Inggris menjadi lebih dan lebih penting. Tetapi bahasa Inggris lisan selalu bagian yang sulit dari belajar bahasa Inggris. Menerapkan prinsip kerja sama dalam belajar berbicara bahasa Inggris dapat kondusif untuk mengembangkan kemampuan lisan siswa, yang dipandang sebagai tujuan akhir lisan pembelajaran bahasa Inggris. Kemudian kompetensi dan kepercayaan diri siswa dapat meningkatkan secara bertahap.

Prinsip kesantunan berbahasa tidak selalu mengandung arti usaha sadar untuk berperilaku sopan, melainkan juga merujuk pada ungkapan-ungkapan berbahasa yang bersifat rutin serta mengacu pada upaya berbicara sopan. Hal ini sejalan dengan Ryabova (2015) melakukan penelitian yang berjudul Politeness Strategy in Everyday Communication. Hasil penelitian ini sebagai pengetahuan untuk memahami norma-norma etika dalam perilaku pidato bahasa Inggris adalah fitur karakteristik budaya komunikasi mereka, yang menentukan pilihan formula dan model komunikasi sehari-hari mereka, mengungkapkan kelas dan status sosial dan beroperasi dalam strategi kesantunan dalam tindak tutur.

Kerja sama antara penutur dan lawan tutur sangat diperlukan agar proses komunikasi dapat berjalan dengan lancar. Setiap peserta pertuturan memberikan konstribusi yang secukupnya atau sebanyak yang dibutuhkan lawan bicara. Hal ini dikemukakan oleh Felemban (2011) dalam jurnal penelitiannya yang berjudul $A$ New Method of Teaching Drama: the pragmatik approach menunjukkan bahwa pendekatan pragmatis direkomendasikan untuk mengajar teks drama (dialog) karena membantu siswa untuk mencapai apa yang dimaksudkan pada makna dari ucapan-ucapan karakter. Dengan demikian, mengesampingkan interpretasi yang tidak terkait. Selain itu, membantu siswa untuk mencapai pemahaman yang lebih baik dari teks-teks sastra pada umumnya.

Penelitian yang dilakukan oleh Felemban memiliki persamaan dan perbedaan dengan penelitian ini. Persamaannya yaitu kedua penelitian ini sama-sama menerapkan kajian pragmatik dan menggunakan prinsip kerja sama. Sedangkan perbedaanya terletak pada fokus penelitiannya yaitu penelitian Felemban fokus dalam pengajaran berbahasa dalam analisis pragmatik teks drama, penelitian ini fokus dalam pengajaran bahasa Indonesia di dalam kelas berkenaan dengan pelanggaran prinsip kerja sama dan pematuhan prinsip kesantunan.

Sejalan dengan penelitian yang dilakukan Methias (2010) berjudul Impoliteness or Underpoliteness: An Analysis of a Christmas dinner Scene from Dicken's Great Expectations menyatakan bahwa fokusnya adalah pada ketidaksopanan yang terjadi dalam pengaturan ramah dari makan malam Natal di antara orang-orang kelas rendah. Sebagai hasil analisis teks, mengusulkan untuk membangun berbagai lain kesopanan. Ketidaksopanan ini dilakukan tanpa niat jahat atau terlepas yang terkadang muncul menjadi rutin dan hasil dari sosialisasi kebiasaan. Namun demikian, mirip dengan jenis lain dari kekasaran itu menciptakan perasaan tidak nyaman, ketidakharmonisan, dan bahkan balas dendam. Analisis ini dilakukan pada tingkat mikro dari ucapan-ucapan tunggal. Terkadang, lebih dari satu ucapan dipertimbangkan untuk rekonstruksi aktivitas percakapan untuk membantu menentukan tingkat yang tepat dari pelanggaran yang terjadi. Metode analisis bergantung pada ketidaksopanan positif dan negatif.

Sebuah percakapan dilakukan untuk menyatakan maksud guna mencapai dan 
mengandalkan pemahaman bersama dan tujuan sosial. Tujuan sosial yang dimaksud juga mengacu kepada penciptaan hubungan harmonis untuk menghindari konflik berdasarkan norma sosial yang berlaku, dalam hal ini tuturan guru dan siswa sebagai unit terkecil percakapan di kelas dipandang sebagai tindak tutur yang mempunyai fungsi dan dampak tertentu. Dalam penelitian Sari (2013) yang berjudul "Pelaksanaan Prinsip Kerja Sama dalam Percakapan Guru dan Siswa serta Dampaknya terhadap Pembelajaran Bahasa Indonesia di Kelas XI SMAN 1 Kediri" menjelaskan bahwa konteks pembelajaran sebagai tempat pelaksanaan prinsip kerjasama di kelas, dominan terjadi padakonteks situasi formal, pada saatguru menjelaskan materi pelajaran.Pelaksanaan prinsip kerja samaterjadi pula pada situasi tidak terlaluformal, tampak pada saat adanyatindak tutur guru dan siswa yangmenegaskan kembali teori yang telahdijelaskan dengan menambahargumen pendukung. Pada situasiinformal, tampak pada saat guruterlibat masalah pribadi dengansiswa, tampak adanya pelaksanaanprinsip kerja sama, tetapi dalam halini prinsip kerja sama tersebut cenderung dilanggar.

Penutur selalu berusaha agar tuturannya relevan dengan konteks, jelas, dan mudah dipahami, padat, dan ringkas, serta selalu pada lingkup pembicaraan atau persoalan sehingga tidak menghabiskan waktu lawan biacaranya. Prinsip kerja sama dilakukan atau dipatuhi oleh penutur dan lawan tuturnya agar proses percakapan berlangsung secara baik dan lancar. Akan tetapi, prinsip kerja sama banyak dalam pertuturan yang dilanggar. Hal ini sejalan dengan Sulistyowati (2008) dengan penelitiannya yang berjudul "Pelanggaran Prinsip Kerja Sama dan Implikatur Percakapan dalam Film Petualangan sherina Karya Riri Reza" menyimpulkan bahwa penelitian tersebut terdapat berbagai macam implikatur percakapan yang timbul karena pelanggaran prinsip kerja sama. Dalam film Petualangan Sherina ditemukan pelanggaran prinsip kerja sama, yaitu maksim kuantitas, maksim kualitas, dan maksim cara. Pelanggaran maksim kuantitas lebih banyak ditemukan karena penutur dan lawan tutur tidak mengikuti prinsip kerja sama. Penutur dan lawan tutur saling memberikan kontribusi yang berlebihan dan tidak ditemukan maksim relevansi karena penutur dan lawan tutur (tokoh-tokoh film) mengikuti prinsip kerja sama dengan baik, sehingga menghasilkan tuturan yang bersifat kooperatif. Selanjutnya, implikatur percakapan yang ditemukan dalam film Petualangan Sherina yang timbul karena adanya pelanggaran prinsip kerja sama terdiri dari macam-macam implikatur yang berbeda. Implikatur tersebut adalah implikatur yang bersifat memberitahukan, menunjukkan, menolak, menyatakan keraguan, menyatakan kebingungan, mengejek, merahasiakan, menyetujui, meminta pemahaman mitra tutur, menyatakan kemarahan, dan menyatakan kebohongan. Hal ini membuktikan bahwa percakapan yang tidak menjalankan prinsip kerja sama akan menghasilkan implikatur dalam sebuah percakapan.

\section{METODE PENELITIAN}

Penelitian ini merupakan penelitian deskriptif kualitatif dengan pendekatan analasis isi.Sumber data dalam penelitian ini adalah dokumen berupa novel terjemahan Harry Potter tahun 1 dan 2, serta catatan lapangan hasil wawancara dengan narasumber. Selain dokumen, sumber data yang lain adalah narasumber, yaitu guru bahasa Indonesia dan siswa kelas VIII SMP Negeri 2 Sragen. Teknik pengumpulan data yang digunakan dalam penelitian ini adalah purposive sampling.Validitas data yang digunakan dalam penelitian ini adalah 
trianggulasi teori, trianggulasi sumber, triangulasi metode, dan review informan.Teknik analisis data dalam penelitian ini menggunakan model analisis interaktif (interaktif modelof analysis).

Seperti apa yang telah dipaparkan sebelumnya, penelitian ini memfokuskan pada tindak tutur direktif, kesantunan berbahasa, dan sebagai relevansi baha ajar di SMP. Degan semua langkah tersebut, diharapkan mampu menemukan beberapa simpulan yang valid dan tepat mengenai fokus penelitian yang penulis susun.

\section{HASIL DAN PEMBAHASAN}

Bentuk Tindak Tutur Direktif dalam Novel Harry Potter Tahun 1 dan 2 Karya J.K Rowling

Berdasarkan pengamatan yang telah dilakukan, bentuk tindak tutur direktif tersebut ditemukan dalam novel Harry Potter tahun 1 dan 2 karya J.K Rowling, antara lain bentuk tuturan direktif permintaan, pertanyaan, memerintah, larangan, pemberian izin, dan bentuk tuturan direktif menasihati. Data bentuk tindak tutur direktif novel Harry Potter tahun 1 dan 2 karya J.K Rowling yang ditemukan berjumlah 419 data. Adapun, jumlah masing-masing bentuk tindak tutur direktif tersebut dapat dipaparkan dalam tabel di bawah.

Tabel 1.Penyebaran Jumlah Data BentukBentuk Tututan Direktif

\begin{tabular}{llcc}
\hline No. & $\begin{array}{c}\text { Bentuk Tindak } \\
\text { Tutur Direktif } \\
\text { Guru }\end{array}$ & $\begin{array}{c}\text { Jumlah } \\
\text { Data }\end{array}$ & Persentase \\
\hline 1 & Permintaan & 114 & $27,2 \%$ \\
2 & Pertanyaan & 56 & $13,4 \%$ \\
3 & Memerintah & 149 & $35,5 \%$ \\
4 & Larangan & 43 & $10,3 \%$ \\
5 & Pemberian Izin & 19 & $4,5 \%$ \\
6 & Menasihati & $\underline{38}$ & $\underline{9,1 \%}$ \\
\hline & $\frac{\mathbf{1 0 0} \%}{\text { Jumlah }}$ & $\underline{\mathbf{4 1 9}}$ & $\underline{\mathbf{1 0 0}}$ \\
&
\end{tabular}

Tabel di atas memaparkan tentang jumlah penyebaran data dari masing-masing bentuk tindak tutur direktif novel Harry
Potter tahun 1 dan 2 karya J.K Rowling. Data di atas menunjukkan bahwa bentuk tindak tutur direktif memerintah memiliki jumlah data yang paling banyak, yakni 149 data atau mencapai 35,5\% dari keseluruhan jumlah data yang ditemukan. Bentuk tindak tutur direktif permintaan berada di posisi kedua dengan jumlah data 114 data atau mencapai $27,2 \%$. Bentuk tindak tutur direktif pertanyaan berada di posisi ketiga dengan jumlah data 56 data atau mencapai 13,4\%. Bentuk tindak tutur direktif larangan berada di posisi keempat dengan jumlah data 43 data atau mencapai $10,3 \%$. Bentuk tindak tutur direktif menasihati berada di posisi kelima dengan jumlah data 38 data atau mencapai $9,1 \%$. Bentuk tindak tutur pemberian izin pada posisi keenam dengan jumlah data 19 data atau mencapai 4,5\%.

Berdasarkan hasil pengamatan yang telah dilakukan, bentuk-bentuk tindak tutur direktif dari novel Harry Potter tahun pertama dan kedua tersebut memiliki perbedaan terkait dengan jumlah penyebaran data. Adapun, penyebaran data dari masingmasing bentuk tindak tutur direktif dapat dipaparkan dan dijelaskan melalui data berikut.

\section{Tindak Tutur Direktif Permintaan}

Tokoh-tokoh dalam novel tersebut menggunakan bentuk tindak tutur direktif permintaan agar penutur dan mitra tutur memberikan sesuatu ataupun menunjukkan respons tertentu sesuai dengan permintaan yang diutarakan oleh lawan bicara tersebut.

(1) "Ya, ya, memang sangat menyedihkan, tetapi kendalikan dirimu, Hagrid. Kalau tidak, kita bisa ketahuan," bisik Profesor McGonagall sambil membelai-belai lengan Hagrid dengan amat hati-hati, sementara Dumbledore melangkahi tembok halaman yang rendah dan berjalan ke pintu depan. (HP $1 / \mathrm{hlm}$. 25) 
Konteks tuturan (1): tururan Profesor Mc Gonagall terhadap Hagrid memintanya untuk mengendalikan dirinya agar tidak menimbulkan suara saat mengendap dibalik tembok.

Data tersebut menunjukkan bahwa tuturan tersebut diutarakan oleh Profesor Mc Gonagall agar Hagrid menunjukkan respons terhadap tuturan tersebut, yakni agar Hagrid berjalan tidak menimbulkan suara yang berisik sesuai dengan keinginan Profesor Mc Gonagall. Profesor Mc Gonagall menggunakan bentuk tuturan tidak langsung, karena maksud tuturan tidak sesuai dengan modus kalimat yang digunakan, yakni kalimat imperatif.

\section{Tindak Tutur Direktif Pertanyaan}

Berdasarkan hasil pengamatan yang telah dilakukan terhadap novel Harry Potter tahun 1 dan 2 karya J.K Rowling sebagai berikut.

(2) "Kau sudah bangun belum?" tunturnya. "Hampir," jawab Harry. (HP 1/hlm. 29)

Konteks tuturan (2):

Bibi Petunia bertanya kepadanya memastikan pada dirinya sudah bangun atau belum, dan dia pun menjawab meyakinkan ke Bibinya itu kalau dia telah bangun dari tidurnya.

Data tersebut menunjukkan bahwa Bibi Petunia menggunakan bentuk tuturan direktif pertanyaan yang ditujukan Harry Potter.Bibinya ingin memperoleh informasi memastikan Harry Potter sudah bangun dari tidurnya atau belum. Dengan demikian, data di atas menggunakan modus kalimat yang sesuai dengan maksud tuturannya.

\section{Tindak Tutur Direktif Memerintah}

Berdasarkan hasil pengamatan yang telah dilakukan terhadap novel Harry Potter tahun 1 dan 2 karya J.K Rowling sebagai berikut.
(3) "Ayo, cepat! Aku mau kau yang menggoreng daging asap. Jangan sampai gosong. Aku ingin segalanya sempurna pada hari ulang tahun Dudlay." (HP 1/hlm. 29)

Konteks tuturan (5): tuturan Bibi Petunia memerintahkan kepada Harry Potter untuk bergegas dan meminta dia menggoreng daging asap untuk makanan dalam acara ulang tahun putranya Dudlay.

Pada data tersebut dapat dilihat konteks tuturan Bibi Petunia terhadap Harry Potter. Tuturan menunjukkan bahwa tuturan tersebut diutarakan oleh bibinya agar Harry melakukan sesuatu yang sesuai dengan keinginan Bibi Petunia, yakni agar Harry Potter menggoreng daging asap untuk makanan dalam acara ulang tahun putra bibinya itu. Bibi menggunakan bentuk tuturan langsung, karena maksud tuturan sesuai dengan modus kalimat yang digunakan, yakni kalimat imperatif sehinggan bentuk tuturan langsung untuk merealisasikan bentuk tuturan direktif memerintah.

\section{Tindak Tutur Direktif Larangan}

Bentuk tindak tutur direktif larangan juga ditemukan dalam situasi novel Harry Potter tahun 1 dan 2 karya J.K Rowling, yakni ketika terjadinya interaksi antara penutur dan mitra tutur. Berdasarkan hasil pengamatan yang telah dilakukan, ditemukan data yang berupa bentuk tuturan direktif larangan sebagai berikut.

(4) "Jangan minta maaf Sir, karena tidak ada yang bisa membuatku marah hari ini! Bergembiralah, karena Kau-TahuSiapa telah pergi akhirnya! Bahkan Muggle seperti Anda pun harus ikut merayakan hari yang amat sangat membahagiakan ini." (HPI/hlm. 12)

Konteks tuturan (7):

Tuturan Hagrid terhadap Dumbledore yang melarang dia untuk mengatakan 
maaf karena kabar yang ia dengan dan berikan merupakan kabar yang bahagia.

Data tersebut menunjukkan Hagrid menggunakan bentuk tuturan direktif larangan yang ditujukan kepada Dumbledore. Hagrid tidak membolehkan Dumbledore untuk meminta maaf ketika disuruh ikut serta dalam menyambut murid dan merayakan hari yang sangat membahagiakan. Hagrid menggunakan bentuk tuturan tindak langsung literal, karena maksud tuturan tidak sesuai dengan modus kalimat yang digunakan, yakni kalimat deklaratif.

\section{Tindak Tutur Direktif Pemberian Izin}

Berdasarkan hasil pengamatan yang telah dilakukan terhadap novel Harry Potter tahun 1 dan 2 karya J.K Rowling tersebut, ditemukan data yang berupa tuturan direktif bentuk pemberian izin sebagai berikut.

(5) "Julurkan tanganmu. Bagus." Dia mengukur Harry dari bahu ke jari, kemudian pergelangan tangan ke siku, bahu ke lantai, lulut ke ketiak, dan sekeliling kepalanya. Sementara mengukur, dia berkata, "Semua tongkat Ollivander punya intisari kegaiban, $\mathrm{Mr}$. Potter. (HPl/ hlm. 107)

Konteks tuturan:

Tuturan tersebut diutarakan oleh $\mathrm{Mr}$. Ollivander sebelum melakukan pengukuran ke badannya untuk mengukur seragam sekolah Harry Potter.

Data tersebut menunjukkan bahwa Mr. Ollivander menggunakan bentuk tuturan direktif pemberian izin yang ditujukan kepada Harry Potter. Tuturan Mr. Ollivander dan respons dari Harry memberikan izin kebebasan untuk mengukur tubuh Harry Potter tersebut.

\section{Tindak Tutur Direktif Menasihati}

Tindak tutur direktif menasihati memiliki penanda tertentu dalam penerapannya. Bentuk tuturan direktif menasihati secara umum direalisasikan dengan menggunakan modus kalimat imperatif. Kalimat imperatif yang mengandung makna anjuran ditandai dengan penggunaan kata hendaknya dan sebaiknya.

Berdasarkan hasil pengamatan yang telah dilakukan terhadap novel Harry Potter tahun 1 dan 2 karya J.K Rowling tersebut, ditemukan data yang berupa tuturan direktif bentuk menasihati sebagai berikut.

(6) "Jangan khawatir, Harry. Kau akan belajar dengan cepat. Semua orang mulai dari awal di Hogwarts, kau tak akan dapat masalah. Jadilah saja dirimu sendiri. Aku tahu ini berat. Kau telah dipilih, dan ini selalu berat. Tetapi kau akan senang di Hogwarts-dulu aku juga-bahkan sampai sekarang pun masih." (HPl/hlm. 111)

Konteks tuturan:

Tuturan tersebut diutarakan oleh Hagrid kepada Harry Potter saat ia merasa gugup ketika akan memulai belajar di Hogwarts. Hagrid menenangkan Harry Potter dan memberikan kepercayaan diri untuk Harry Potter.

Data tersebut menunjukkan bahwa Hagrid menggunakan bentuk tuturan direktif menasihati yang ditujukan kepada Harry Potter. Hagrid menunjukkan suatu kepercayaan kepada Harry Potter bahwa dengan memberikan nasihat dan membangun kepercayaan diri Harry Potter dapat menimbulkan semangat dia dalam mengikuti sekolah dan belajarnya di Hogwarts. Hagrid menggunakan bentuk tuturan langsung, karena maksud tuturan sesuai dengan modus kalimat yang digunakan.

\section{Kesantunan Berbahasa Tindak Tutur Direktif}

Berdasarkan pengamatan yang telah dilakukan, pematuhan prinsip kesantunan tersebut ditemukan dalam interaksi antara 
guru dan siswa di dalam kelas. Dalam pembelajaran bahasa Indonesia, terdapat tuturan yang mengandung pematuhan prinsip kesantunan, yaitu maksim kebijaksanaan, maksim kemurahan, maksim penerimaan, maksim kerendahan hati, maksim kecocokan, dan maksim kesimpatian. Data pematuhan prinsip kesantunan guru dan siswa yang ditemukan berjumlah 59 data. Jumlah masing-masing pematuhan prinsip kesantunan dapat dipaparkan dalam tabel di bawah.

\begin{tabular}{|c|c|c|c|}
\hline No. & Prinsip Kesantunan & $\begin{array}{c}\text { Jumlah } \\
\text { Data }\end{array}$ & Presentase \\
\hline 1 & Maksim & 26 & $22,03 \%$ \\
\hline 2 & $\begin{array}{l}\text { Kebijaksanaan } \\
\text { Maksim Kemurahan }\end{array}$ & 20 & $16,94 \%$ \\
\hline 3 & Maksim Penerimaan & 14 & $11,86 \%$ \\
\hline 4 & $\begin{array}{l}\text { Maksim Kerendahan } \\
\text { Hati }\end{array}$ & 10 & $8,47 \%$ \\
\hline 5 & Maksim Kecocokan & 36 & $30,5 \%$ \\
\hline \multirow[t]{2}{*}{6} & $\begin{array}{l}\text { Maksim } \\
\text { Kesimpatian }\end{array}$ & 12 & $10,2 \%$ \\
\hline & Jumlah & $\underline{118}$ & $100 \%$ \\
\hline
\end{tabular}

Tabel di atas memaparkan tentang jumlah data bentuk prinsip kesantunan yang ditemukan selama proses membaca berlangsung. Data di atas menunjukkan bahwa bentuk kesantunan tindak tutur direktif novel Harry Potter tahun 1 dan 2 maksim kecocokan memiliki jumlah data yang paling banyak, yakni 36 data atau mencapai $30,5 \%$ dari keseluruhan jumlah data yang ditemukan. Bentuk kesantunan tindak tutur direktif maksim kebijaksanaan di posisi kedua dengan jumlah data 26 atau mencapai 22,03\%. Diposisi ketiga, bentuk kesantunan tindak tutur direktif maksim kemurahan memiliki jumlah data 20 atau mencapai $16,94 \%$. Bentuk kesantunan tindak tutur direktif maksim penerimaan memiliki jumlah data 14 atau mencapai $11,86 \%$. Bentuk kesantunan tindak tutur direktif maksim kesimpatian memiliki jumlah data 12 atau mencapai $10,2 \%$. Terakhir maksim kerendahan hati memiliki jumlah data sebanyak 10 atau mencapai $8,47 \%$.
Berdasarkan hasil pengamatan yang telah dilakukan, bentuk kesantunan berbahasa tindak tutur direktif dalam novel Harry Potter tahun 1 dan 2 memilikiperbedaan terkait dengan jumlah data yang ada. Adapun, penyebaran data dari masing-masing pematuhan bentuk kesantunan dapat dipaparkan dan dijelaskan melalui data berikut.

\section{Maksim Kebijaksanaan}

Berikut ini adalah salah satu contoh bentuk kesantunan maksim kebijaksanaan yang terdapat pada novel Harry Potter tahun 1 dan 2 karya J.K Rowling:

(7) "Silakan duduk," kata Harry sopan, menunjuk tempat tidurnya. (HP2/hlm. 21)

Konteks tuturan (13): tuturan tersebut disampaikan oleh Harry kepada Mr. dan Mrs. Mason untuk mempersilakan duduk di tempat tidurnya.

Pada percakapan tersebut terdapat pematuhan terhadap maksim kebijaksanaan, khususnya submaksim pertama karena membuat kerugian orang lain sekecil mungkin. Kesantunan terlihat pada tuturan Harry, "Silakan duduk". Tuturan tersebut disampaikan oleh Harry kepada Mr. dan Mrs. Mason. Tuturan tersebut termasuk dalam tindak tutur direktif karena merupakan tuturan mempersilakan.Tuturan silakan adalah penanda lingual dari tindak tutur direktif 'mempersilakan'.

\section{Maksim Kemurahan}

Berikut ini adalah salah satu contoh bentuk kesantunan berbahasa tindak tutur direktif maksim kemurahan yang terdapat pada dalam novel Harry Potter tahun 1 dan 2 karya J.K Rowling:

(8) "Jangan ragu menghubungiku. Aku selalu senang membagikan keahlianku pada pemain yang kurang terampil dibanding aku...” (HP2/ hlm. 202) 
Konteks tuturan (15):

Tuturan tersebut mengutarakan bahwa Ron akan menghadapi bila ada serangan yang mencurigakan tersebut datang kembali dihadapan mereka, dan menenangkan Hermione yang merasa gugup akan kejadian ini.

Pada percakapan tersebut terdapat pematuhan maksim kemurahan, khususnya submaksim yang pertama mengurangi keuntungan diri sendiri. Pematuhan terlihat pada tuturan Ron, "Jangan ragu menghubungiku. Aku selalu senang membagikan keahlianku pada pemain yang kurang terampil dibanding aku..."Tuturan tersebut termasuk dalam tindak tutur asertif karena menginformasikan. Tuturan Jangan ragu menghubungiku adalah penanda lingual dari tindak tutur asertif 'menginformasikan'.

\section{Maksim Penerimaan}

Berikut ini adalah salah satu contoh kesantunan berbahasa maksim penerimaan tindak tutur direktif yang terdapat pada yang terdapat pada dalam novel Harry Potter tahun 1 dan 2 karya J.K Rowling:

(9) "Mendekat, mendekat! Apa semua bisa melihatku? Semua bisa mendengarku? Bagus sekali!" (HP2/ hlm. 235)

Konteks tuturan (17):

Tuturan Lockhart tersebut memberikan informasi bahwa dia sedang menggunakan jubah ajaib.Sehingga dia memastikan apakah orang-orang masih bisa melihat dan mendengarnya atau tidak.

Pada percakapan data tersebut di atas terdapat pematuhan terhadap maksim penerimaan yaitu submaksim kedua dengan meminimalkan keuntungan diri sendiri.Bentuk penerimaan yang terdapat dalam percakapan tersebut dituturkan oleh Lockart kepada temannya dengan tuturan "Mendekat, mendekat!Apa semua bisa melihatku? Semua bisa mendengarku?Bagus sekali!” yang merupakan suatu bentuk tindak tutur ekspresif 'memuji'.Dalam tuturan tersebut, Lockart menunjukkan rasa kekaguman atau pujiannya kepada jubah milik Harry dengan memuji bahwa dia menghilang dengan jubah tersebut.

\section{Maksim Kerendahan Hati}

Berikut ini adalah salah satu contoh kesantunan berbahasa maksim kerendahan hati tindak tutur direktif yang terdapat pada dalam novel Harry Potter tahun 1 dan 2 karya J.K Rowling:

(10) "Bagaimana kalau Kami harus menulis karangan tentang pahlawan yang kamikagumi di sekolah, $\mathrm{Mr}$ Mason, dan saya menulis tentang Anda.", tanya Harry. (HP2/ hlm. 13)

Konteks tuturan (19):

Tuturan Harry akan mengagumi sosok seseorang yang bernama Mr. Mason sehingga dia ingin menulis karangan tentang Mr. Mason bila dia mendapat tugas sekolah menulis karangan tentang pahlawan.

Kesantunan berbahasa maksim kerendahan hati yang terdapat pada data tersebut dituturkan oleh Harry kepada Mr. Mason. Kesantunan berbahasa maksim kerendahan hati terutama submaksim kedua meminimalkan rasa hormat pada diri sendiri. Pada saat itu guru mengawali pembelajaran dengan menyapa siswa dengan penuh semangat untuk memberikan sesuatu yang positif dituturkan "Bagaimana kalau Kami harus menulis karangan tentang pahlawan yang kami kagumi di sekolah, Mr Mason, dan saya menulis tentang Anda.", tanya Harry.Kemudian Mr. Mason menanggapi dengan tersenyum. Tuturan Harry tersebut merupakan kesantunan berbahasa maksim kerendahan hati, yaitu meminimalkan rasa hormat pada diri sendiri.Tuturan tersebut termasuk tindak tutur asertif 'menyatakan' karena penutur memberikan pernyataan bahwa dirinya dalam keadaan yang baik dan penuh semangat 


\section{Maksim Kecocokan}

Berikut ini adalah salah satu contoh kesantunan berbahasa maksim kecocokan yang terdapat pada novel Harry Potter tahun 1 dan 2 karya J.K Rowling tersebut:

(11) "Ikut aku, Argus," katanya kepada Filch. "Kalian juga, Mr Potter, Mr Weasley, Miss Granger." Kata Dumbledore. "Iya, Sir!", jawab mereka serentak. (HP2/ hlm. 175)

Konteks tuturan (21): tuturan yang diutarakan oleh Dumbledore kepada anak-anak muridnya di Hogwart untuk mengikutinya mengelilingi ruangan yang ada di sana.

Pada percakapan tersebut terdapat kesantunan berbahasa terhadap maksim kecocokan, khususnya submaksim pertama yaitu memaksimalkan kesetujuan di antara mereka.Pematuhan maksim kecocokan terjadi antara Dumbledore dan beberapa muridnya saat mengelilingi sekolah itu. Pematuhan maksim kecocokan dituturkan oleh muridnya, yaitu pada tuturan "Iya, Sir!'.Tuturan tersebut termasuk tindak tutur asertif, yaitu menyetujui terhadap suatu hal.

\section{Maksim Kesimpatian}

Berikut ini adalah salah satu contoh kesantunan berbahasa maksim kesimpatian tindak tutur direktif yang terdapat pada novel Harry Potter tahun 1 dan 2 karya J.K Rowling:

(12) "Bergembiralah, karena Kau-TahuSiapa telah pergi akhirnya! Bahkan Muggle seperti Anda pun harus ikut merayakan hari yang amat sangat membahagiakan ini." (HP1/ hlm. 12)

Konteks tuturan: tuturan yang diutarakan oleh Hagrid kepada Dumbledore agar bergembira dengan kabar yang didapat karena sekolah di Hogwart akan membuka dan menerima murid baru sehingga peristiwa tersebut harus dirayakan secara meriah dan suka cita menyambutnya.

Pada percakapan tersebut terdapat pematuhan terhadap maksim kesimpatian, khususnya submaksim pertama karena memaksimalkan rasa simpati kepada mitra tuturnya.Pematuhan terhadap maksim kesimpatian dilakukan oleh Hagrid kepada Dumbledore.Kesantunan berbahasa tindak tutur direktif dapat dilihat pada tuturan "Bergembiralah, karena Kau-Tahu-Siapa telah pergi akhirnya! Bahkan Muggle seperti Anda pun harus ikut merayakan hari yang amat sangat membahagiakan ini". Tuturan tersebut termasuk tindak tutur asertif karena Hagrid menunjukkan rasa senang.Tuturan Terima kasih untuk perhatiannya, kalian memang luar biasa adalah penanda lingual tindak tutur asertif 'menunjukkan rasa senang'.

\section{Relevansi Novel Harry Potter dengan Pembelajaran Sastra di SMP}

Novel Harry Potter tahun 1 dan 2 karya J. K. Rowlingjika dikaitkan dengan pembelajaran sastra di Sekolah Menengah Pertama (SMP) sudah sesuai. Standar Kompetensi (SK) pada Kurikulum Tingkat Satuan Pendidikan (KTSP) yang membahas tentang novel terdapat pada kelas VIII semester genap, yaitu: 13. Memahami unsur intrinsik novel remaja (asli atau terjemahan) yang dibacakan. Berdasarkan wawancara dari guru bahasa Indonesia kelas VIII SMP Negeri 2 Tangen, Sragen, unsur intrinsik selalu diberikan kepada peserta didik. Mulai dari tema, alur, tokoh, latar, sudut pandang, dan amanat.Bahan pembelajaran yang dipilih oleh guru pun mempertimbangkan perkembangan peserta. Jadi novel Harry Potter tahun 1 dan 2 karya J. K. Rowling dapat dijadikan bahan pembelajaran sastra di SMP. 


\section{SIMPULAN}

Berdasarkan hasil temuan penelitian dan pembahasan di atas, maka dapat disimpulkan sebagai berikut: (1) tindak tutur; permintaan, pertanyaan, memerintah, larangan, pemberian izin, dan bentuk tuturan direktif menasihati yang berjumlah 419 data;(2) pematuhan prinsip kesantunan guru

\section{REFERENSI}

Lestari, Ika. (2013). Pengembangan Bahan Ajar Berbasis Kompetensi. Padang: Akademia Permata.

Li, Qun. (2015). The Application of Cooperative Principle in Oral English Learning. International Journal on Studies in English Language and Literature. vol 3. (1). pp. 39-48.

Methias, Norice W. (2010). Impoliteness or Undepoliteness: An analysis of a Christmas Dinner Scene from Dickens's Great Expectation. Journal of King Saud UniversityLanguages and Translations, 3 (3), 11-18.

Nadar, F.X. (2009). Pragmatik dan Penelitian Pragmatik. Yogyakarta: Graha Ilmu.

Rohmadi, Muhamad. (2004). Pragmatik Teori dan Analisis. Yogyakarta: Lingkar Media

Ryabova, Marina. (2015). Politeness Strategy in Everyday Communication. $X V$ International Conference "Linguistic and Cultural Studies Traditions and Innovations"Rusia. dan siswa selama proses pembelajaran berlangsung ditemukan sebanyak 118 data;(3) novel Harry Potter tahun 1 dan 2 karya $J$. K. Rowling ada keterkaitandengan pembelajaran sastra di Sekolah Menengah Pertama (SMP).

Sari, Ni Wayan Eminda. (2013). Pelaksanaan Prinsip Kerja sama dalam Percakapan Guru dan Siswa serta Dampaknya terhadap Pembelajaran Bahasa Indonesia di Kelas XI SMAN 1 Kediri. Jurnal Santiaji Pendidikan, 3(2), 178-189.

Sobhani, Arezou and Ali Saghebi. (2014). The Violation of Cooperative Principles Four Maxims in Iranian Psychological Consultation. Journal ofScientific Research.vol 4 (2), 91-99.

Tajabadi, Azar. (2014). Grice's Cooperative Maxims in Oral Arguments: The Case of Dispute Settlement Councils in Iran. International Conference on Current Trends in ELT.

Wardhani D.R, Rossida Ayu. (2014). Tindak Tutur Direktif Dan Strategi Kesantunan Berbahasa Dai Pada Wacana Dakwah Dialogis Acara "Kata Ustad Solmed", "Sarapan Hati", Dan "Cahaya Hati" Di Televisi. 